\title{
VARIABLES PERCEIVED BY MANAGERS AS ANTECEDENTS THAT LEAD FIRMS TO ENVIRONMENTAL MANAGEMENT: AN EMPIRICAL RESEARCH IN THE TURKISH CONSTRUCTION SECTOR
}

Caglar BEKIROGLU

Oya ERDIL

Lutfihak ALPKAN

Gebze Institute of Technology, Turkey

\begin{abstract}
Environmental issues have constituted problems that effect simultaneously all humans, nations and firms. Their effects are widened by the time. To protect the natural environment and to offer a sustainable future to the next generation have become a common target for humanity. As far as countries are concerned, preventing foreign-source dependence with respect to limited resources has become a more important objective by the time. It is being observed that especially firms which have recognized that they can not achieve the desired results through cost competition have recently turned their faces toward environmental management as a new competition strategy. It is possible that the firms create new markets and ensure competitive advantage through protection of the natural environment. The main objective of this study is to examine what the managers perceive as antecedents that lead firms to environmental management. This is at the same time the originality of the present study. These antecedents that may be considered as the first chain of previous studies, make a complementary and integral contribution to the incomplete part.
\end{abstract}

Key Words: Environmental management, national environmental characteristics, eco-efficiency, firm past performance, environmental sensitivity

\section{INTRODUCTION}

Traditional factors of success in business such as product and process technologies, less restrictive regulatory conditions in the market, availability of financial resources and economy of scale are not any more so preeminent (Eren, 2003). The firms that are targeted to the cost leadership must produce a wide range of all related products, provide their services to all important customer segments, make considerable capital investments and continuously strive for facility modernization. The prices of the basic raw materials are almost same in the global markets (Bekiroğlu, 2010). The production facilities, prominent business centers and most importantly the finance force are heading from West to East now and determine a new center line for the world (Arslan, 2010). Since machinery and mould costs are much less in the East, this advantage is skillfully used by the competitors that would normally need to make considerable capital in vestments and investments to the facility modernization in order to enter into that specific markets. It is known by everybody that the Western countries transferred their production operations to the Eastern countries in order to reduce the labour costs (Bekiroğlu, 2010).

The product technology protected under patent and know-how reduced its profitable effects because of the decreasing product-life cycles. New product launch is accelerated. In order to make continuous innovations, the firms are now forced to dynamically monitor all changes in the market and in the relevant technologies and provide immediate feedback to the market needs. This can be only achieved with a work force having superior performance. The patent's profitable effect is also impaired through instant imitation of the innovation with small changes added of course. Besides that, your competitors are generally partners with the suppliers, machine providers and raw material suppliers of your firm. Therefore, if you want to benefit from the technology supported by these suppliers, mould manufacturers, machine manufacturers and raw material suppliers, you have to implement that technology faster and more efficiently than your competitors. Deregulation destroys the governmental arrangements and regulatory policies established for protection against the foreign competition (Eren, 2003).

Energy is not only an economic and ordinary product but also a strategic product that has direct relations with the country's economy and security (Teori, 2010). Since energy is the basic and non-replaceable component of all products, it is strategic (Esinoğlu, 2010). In 1990, Turkey provided 48\% of its energy requirements from local resources, but in the past 20 years, Turkey's dependence on foreign energy resources increased by $50 \%$ and reached to $73 \%$ (Türkyılmaz, 2010). 
Presently we know that petroleum resources will be consumed within the coming 43 years and this period is 65 years for natural gas and 155 years for coal. World population was 6 billion in 1999 and by 2012 it is expected that the population will rise to 7 billion. Diminishing resources, ever increasing population and climatic changes force the world to look for alternative sources of energy (Bekiroğlu, 2010).

Recently, the global strategy preferred by the entities is to evade from the negative effects of competition by adding innovations to their products and systems through establishment of standards and regulations and performance of research studies. This approach is called environmental management and strategy (Bekiroğlu, 2010).

It is observed that the concepts of environmental strategy, environmental management, environmental performance, economic performance and organizational performance and the relationship between these concepts have been examined in the literature. However, studies concerning the factors leading to environmental management are withnessed to be rare. And, none of these limited number of studies addresses such factors as a whole. In the present study, however, the motivators that effect the intentions of business managers to implement environmental sensitivity and environmental management shall be considered.

This article is organized in the following order: First, the notion of the intention of the managers to implement environmental management shall be considered as referred in the research model. Second, the overall definition and review of the concepts of national environmental characteristics, stakeholder pressures, ecoefficiency, firm past performance, strategic priority, customer environmental sensitivity, public environmental sensitivity, environmental sensitivity of the managers and external uncertainty and the way these concepts effect the intentions of managers to implement environmental management shall be discussed respectively. Following the explanation of each antecedent, hypotheses shall be developed. Third, a research model for dependent variables and independent variables shall be put forward. Lastly, these hypotheses shall be tested using 202 questionnaires completed by the managers of the Turkish Construction Sector. Finally, upon describing the analytical procedures and the statistical techniques used in the research, the findings of the investigation are presented and the managerial and theoretical implications are discussed.

\section{DEFINING INTENTION OF MANAGERS TO IMPLEMENT ENVIRONMENTAL MANAGEMENT}

The intention of managers to implement environmental management is addressed through 6 sub-concepts: the importance attached to the measurement of general and special environmental performance indicators, use of environmental performance indicators, environmental budget activities, use of environmental performance indicators in employee evaluation, environmental strategic planning and management.

Environmental performance indicators represent financial or non-financial numerical measurements which give key information on the impact of the firm on the environment, its compliance with regulations, stakeholder relations and organizational systems (Veleva and Ellenbecker, 2000; Ilinitch et al., 1998; Chinander, 2001). Therefore, it is very important to measure environmental performance indicators and these could be divided into 2 sub-groups. First, organizations assume more environmental responsibilities as a result of new laws, regulations and penalties established in environmental issues. Today organizations are obligated to measure, control and declare their environmental performance. Second, reliable environmental performance indicators support the firms in achieving their environmental goals and provide the necessary information for decision making in environmental issues. Third, the organizations demand convincing evidences about the benefits of environmental activities while deciding to allocate their limited resources for the solution of environmental problems. Thus, the environmental systems provide the necessary information on risk cost and measurement relating to a particular investment. Finally, the environmental performance indicators are very efficient instruments in the improvement of the business performance and organizational performance.

Four basic components concerning the use of environmental performance indicators are to monitor internal compliance with environmental policies and regulations, to motivate continuous improvement, to provide data for internal decision making and to provide data for external reporting (Henri and Journeault, 2008a). The three basic components of a budget detailing are the environmental expenses, environmental investments and incomes from material scrap or recycled wastes. In this study, use of environmental performance indicators is elucidated on the basis of seven components.

Environmental budget activities describe the activities of the managers to explain, report and trace the causes of environmental budget variances (Henri and Journeault, 2008c).

The integration of environmental performance indicators in employee evaluation ensures that the managerial effort is in line with environmental activities. It aims the use of environmental criteria in the evaluation process to this end (Gabel and Sinclair-Desgagné, 1993). Incentives may be used for the following aims: for encouraging the managers to focus on activities related to profit and environmental impacts (Lothe ve 
diğ., 1999); for motivating the employees to establish a balance between the priorities of their organization and eco-efficiency (Epstein, 1996); for motivating the employees to spend extra effort in order to improve eco-efficiency (Bonner ve diğ., 2000); for sending a clear message by the top management to the employees about the importance of eco-efficiency for their organization (Epstein, 1996).

Environmental strategic planning is a multi-dimensional system that brings together environmental issues (Ramanujam et al., 1986; Judge and Douglas, 1998). Implementation of environmental strategic planning process has the following benefits: access to more extensive and quality information that could support the improvement of environmental sensitivity in the top managers (Stead ve Stead, 1995); increasing by all employees of the time spent for and interest shown to the environmental performance (Judge ve Douglas, 1998); reduction of costs arising from unnecessary wastes and arrangements by the organizations by correctly choosing the required environmental activities and investments and gaining competitive advantages in this way (Judge ve Douglas, 1998)

The series of ISO 14000 standards developed by ISO defines different aspects of the environmental management (Veleva ve Ellenbecker, 2000). ISO 14001 as an environmental management system represents a structural approach to the determination of environmental goals and targets; to the achievement of these goal and targets; and finally to the confirmation of this achievement by the managements (Veleva ve Ellenbecker, 2000). Environmental management systems, which is a series of voluntary standards, is conceptualized to encourage organizations to express systematically the environmental impacts of their activities (Pringle et al., 1998). The firms implementing ISO 14011 standards shall gain the following advantages: more efficient utilization of the organizational resources and structures in order to gather better and more extensive data on the environmental applications (Marshall ve Brown, 2003); minimization of risks by the measurement of investments (Marshall ve Brown, 2003); establishment of targets to reduce the environmental impacts; developing more loyalty in the top management toward the environmental problems (Marshall ve Brown, 2003); enhancement of profitability and competitive edge (Martin, 2005); and gaining reputation in the eyes of stockholders, general public and financial investment groups (Martin, 2005).

\section{FACTORS INFLUENCING INTENTION OF MANAGERS TO IMPLEMENT ENVIRONMENTAL MANAGEMENT}

In this study, nine factors influencing intention of managers to implement environmental management are examined. These factors are namely national environmental characteristics, stakeholder pressures, ecoefficiency rates, firm's past performance, strategic priority, customer environmental sensitivity, public environmental sensitivity, environmental sensitivity of manegers and external uncertainty.

\section{National Environmental Characteristics}

The national environmental characteristics indicate the power of the environmental features of the country to lead firms to environmental management. Of these features, as the national development level increases, it is possible that the pressure of the country on firms concerning environmental issues also increases (Albino et al., 2009; Barik and Pradhan, 1999; Sarmentoa et al., 2007; Wagner and Schaltegger 2004). As public visibility in the country for trade limitations, fines, etc. for commodities that harm the environment increases, the tendency of firms to implement environmental management and strategy also increases (Henri and Journeault, 2008c; Künar et al., 2010). Likewise, dissemination of incentives such as tax reduction, privileged (lower interest and longer term) loans etc. will accelerate this process in the firms (Keskin, 2009). Additionally, the increase in total primary energy consumption compared to the population or the gross national product will highlight both the consumption of resources and the environmental issues on firms with respect to foreign-source dependence (TMMOB, 2009a; TMMOB, 2009b). The increase in total $\mathrm{CO} 2$ emission in the country compared to total primary energy consumption will firstly force the country to go down below the limit values undertaken by international environmental agreements and hence will direct the firms in this respect (Kent, 2008; TMMOB, 2009a; TMMOB, 2009b). As a consequence, with the effect of the characteristics of the country, the environmental sensitivities and intentions of the managers of the firms of such country toward environmental management implementations will increase.

H1: There is a positive relationship between the national environmental characteristics and the intention of managers to implement environmental management.

\section{Stakeholder Pressures}

Stakeholder pressures are defined as influence put by individuals or groups on a company (Henriques and Sadorsky, 1999). Companies facing a higher level of stakeholder pressure channel themselves towards environmental management in order to be able to persuade their stakeholders that their investments and operations are not carrying significant risks (Al-Tuwaijri et al., 2004). Stakeholder pressures can be grouped under 4 main headings as international environment, national environment, local environment and 
business itself. International environment sub-group of stakeholder pressures comprises international customers, suppliers, competitors, aggrements, and economic, technological, socio-cultural, political, natural environment, as well as religious and moral conditions (Albino et al., 2009; Çelik, 2010; Delmas and Toffel, 2004; Denton, 1998; Hamans, 2009a; Hamans, 2009b; Hamans, 2009c; Hamans, 2009d; Hamans, 2009e; Henri ve Journeault, 2008a; Hoffman, 2000; Huybers and Bennett, 2003; IMSAD, 2010a; IMSAD, 2010b; Keskin, 2009; Mebratu, 2001; TMMOB, 2009a; Wagner and Schaltegger 2004; Yayan, 2007; Yontar, 2008). National environment sub-group of stakeholder pressures comprises national media, government, community, courts, and economic, technological, socio-cultural, political, natural environment, as well as religious and moral conditions (Barik and Pradhan, 1999; Bayram, 2009; Delmas and Toffel, 2004; European Commission release, 2010; European Construction Forum, 2010; Hamans, 2009a; Henri and Journeault, 2008a; Hoffman, 2000; IMSAD Sürdürülebilir Gündem Platformu, 2010b; IMSAD Sürdürülebilir Gündem Platformu, 2010c; Keskin, 2009; Martin, 2005; T.C. Bayındırlık ve İskan Bakanlığı, 2010; T.C. Çevre ve Orman Bakanlığı, 2010; T.C. Elektrik İşleri Etüt İdaresi Genel Müdürlüğü Enerji Kaynakları Etüt Dairesi Başkanlığı, 2010; T.C. Enerji ve Tabii Kaynaklar Bakanlığı, 2008; The Energy Efficiency Action Plan Taskforce (E2APT), 2010; Wagner and Schaltegger 2004; Yayan, 2007). Local environment sub-group of stakeholder pressures comprises domestic local, suppliers, shareholders, financial institutions, competitions, environmental non-governmental organizations, regional or municipal administrative units, local public departments, insurance companies, retailers, distributors, trade unions, scientific institutions, industrial associations, consultants, purchasers (companies), consumer's associations and trade associations (Barik and Pradhan, 1999; Bayram, 2009; Delmas, Toffel, 2004; Denton, 1998; European Commission release, 2010; European Construction Forum, 2010; Hamans, 2009a; Henri and Journeault, 2008a; Hoffman, 2000; IMSAD Sürdürülebilir Gündem Platformu, 2010b; IMSAD Sürdürülebilir Gündem Platformu, 2010c; Keskin, 2009; Mebratu, 2001; T.C. Bayındırlık ve İskan Bakanlığ1, 2010; T.C. Çevre ve Orman Bakanlığı, 2010; T.C. Elektrik İşleri Etüt İdaresi Genel Müdürlüğü Enerji Kaynakları Etüt Dairesi Başkanlığı, 2010; T.C. Enerji ve Tabii Kaynaklar Bakanlığı, 2008; The Energy Efficiency Action Plan Taskforce (E2APT), 2010; Wagner ve Schaltegger 2004; Yayan, 2007). Business sub-group of stakeholder pressures comprises employees and executive personnel (Chiang and Tseng, 2005; Clausen et al., 2003; Denton, 1998; Hamner, 1999; Hamner, 2005; Henri and Journeault, 2008a; Hoffman, 2000; Wagner and Schaltegger 2004; Yayan, 2007). Therefore, under influence of stakeholders, it is highly likely that executive personnel working at companies more heavily influenced by stakeholder pressures will be more tempted to adopt environmental responsiveness and environmental management practices.

$\mathrm{H} 2$ : There is a positive relationship between the stakeholder pressures and the intention of managers to implement environmental management.

\section{Eco-Efficiency Rates}

Eco-efficiency rates can be very shortly formulated as to do more using less. Eco-efficiency on one hand reduces the environmental impacts of firms, and on the other hand it expresses the win-win state of achieving value creating targets. In the present study, 3 ratios recognized as eco-efficiency ratios are used. The first eco-efficiency ratio is the ratio of energy consumption (\$) to sales (\$)(Albino et al., 2009; Denton, 1998; Henri and Journeault, 2008a; Henri and Journeault, 2008b; Hontou et al., 2007; Mebratu, 2001; Sarmentoa et al., 2007). The second eco-efficiency ratio is the ratio of material consumption (\$) to sales (\$) (Albino et al., 2009; Denton, 1998; Henri and Journeault, 2008b; Hoffman, 2000; Mebratu, 2001; Wagner and Schaltegger 2004). The third eco-efficiency ratio is the ratio of wastes (\$) to sales (\$) (Denton, 1998; Henri and Journeault, 2008a; Henri and Journeault, 2008b; Mebratu, 2001). As the amounts of energy consumption, material consumption and waste of firms within total sale increases, the tendency of firms to implement environmental management will increase. Thus, with the effect of the firm eco-efficiency ratios, the environmental sensitivities and intentionality of managers of such firms to environmental management implementations will increase.

H3: There is a positive relationship between the eco-efficiency rates and the intention of managers to implement environmental management.

\section{The Firm's Past Performance}

The firm's past performance defines the recent financial and organizational structure change of the firm. A positive change in financial and organizational structure directs firms to environmental management. In previous studies it is stated that the increases in three components of the financial structure, namely profit rate (Brammer and Pavelin, 2008; Hontou et al., 2007; Wagner and Schaltegger 2004), financial resources (Brammer and Pavelin, 2008; Clausen et al., 2003; Hamans, 2009a; Hoffman, 2000; Orsato, 2006; Wagner and Schaltegger 2004) and turnover (Wagner and Schaltegger, 2004) increases the environmental sensitivity of firms. Furthermore, it has been 
considered that the increases in two components of the organizational structure, number of employees (Brammer and Pavelin, 2008; Clausen et al., 2003; Delmas and Toffel, 2004; Esty and Porter, 2005; Henri and Journeault, 2008a; Sarmentoa et al., 2007; Wagner and Schaltegger 2004) and level of institutionalizing, leads (directs) firms toward environmental management. Thus, with the effect of the past performance of a firm, the environmental sensitivities and intentionality of managers of such firms to environmental management implementations will increase.

H4: There is a positive relationship between the firm's past performance and the intention of managers to implement environmental management.

\section{Strategic Priority}

Strategic priority can be expressed as a path preferred by individual companies for achievement of its objectives. In this study, strategic priority has been created by adding an environmental component to manufacturing strategies. Manufacturing strategy can be defined as an effective use of manufacturing performance as a competitive weapon for achievement of business objectives. In the literature, factors used to measure manufacturing strategy include production flexibility, quality improvement, costcutting and lead time (Van Dierdonck and Miller, 1980; Hayes and Wheelwright, 1984; Wheelwright, 1984; Youndt et al., 1996; Ward and Duray, 2000). In other words, dimensions of production flexibility, quality improvement, cost-cutting and lead time have been used as four competitive priorities for rendering production strategy measurable (Van Dierdonck and Miller, 1980; Hayes and Wheelwright, 1984; Wheelwright, 1984; Youndt et al., 1996; Ward and Duray, 2000). Innovation as a 5th dimension has been added to this measurement by Hayes et all (1988). Lastly, environmental dimension has been added as 6th dimension. Environment is a dimension which has been discussed in various studies in the literature (Claver et al., 2007; Curcio and Wolf, 1996; Hamner, 2001; Hamner, 2005; Henri and Journeault, 2008a; Henri and Journeault, 2008b; Henri and Journeault, 2008c; Hontou et al., 2007; Pfeffer, 2005; Wagner and Schaltegger 2004). As importance given to environmental dimension as strategic priority rises, individual companies would have to exhibit a growing inclination towards environmental issues. For that matter, when a company strategically gives a higher importance to environment, executive personnel of that company would be more tempted to adopt environmental responsiveness and environmental management practices.

H5: There is a positive relationship between the strategic priority and the intention of managers to implement environmental management.

\section{Customer Environmental Sensitivity}

Customer environmental sensitivity can be expressed as importance given by customers to environmental issues. Level of environmental awareness is expected to go up as time goes by as a consequence of environmental issues arising and this would push environmental responsiveness level further higher. A growing customer environmental sensitivity would, when so perceived by company executives, drive such executives to adopt environmental management practices. Expressions outlined in previous studies with respect to customer environmental sensitivity are as follows: Foreign environment-friendly products have been plentiful in the domestic market (Hontou et al., 2007; Wagner and Schaltegger 2004). Generally, the number of environmentally-conscious customers has increased day by day (Hontou et al., 2007, Wagner and Schaltegger 2004). Price sensitivity of customers has decreased (Hontou et al., 2007). Customer loyalty toward firms producing environment -friendly products has increased (Hontou et al., 2007). Customers have consented to pay extra for goods that are recyclable and less harmful to the environment (Denton, 1998). For that matter, thanks to influence put on them by customers' environmental sensitivity, executive people working at companies serving for that kind of customer group would be more tempted to adopt environmental sensitivity and environmental management practices.

H6: There is a positive relationship between the customer environmental sensitivity and the intention of managers to implement environmental management.

\section{Public Environmental Sensitivity}

The public environmental sensitivity indicates the sensitivity of individual concerning environmental issues. The increase of worries concerning the environment of the future increases the environmental sensitivity of individuals. The increase in public environmental sensitivity perceived by the firm managers increases the intentionality of managers to implement environmental management. In 
previous studies, the expressions concerning public environmental sensitivity are as follows: In the future, access to energy will become more difficult (Hamans, 2009a; Kent, 2008; Keskin, 2009; TMMOB, 2009a; TMMOB, 2009b; TMMOB, 2009c; Smith, 2007). In the future, climate changes will become a much more serious problem (Hamans, 2009a; TMMOB, 2009c). In the future, Resources will become even more scarce (Hamans, 2009a; Kent, 2008; TMMOB, 2009b; TMMOB, 2009c). In the future, firms will have to reduce resource wastefulness and increase efficiency (Hamans, 2009a). In the future, resources will be more expensive (Hamans, 2009a; Kent, 2008; TMMOB, 2009a; TMMOB, 2009b; TMMOB, 2009c). In the future, firms causing harm to the environment will confront more fines (Keskin, 2009). Thus, with the effect of public environmental sensitivity, the environmental sensitivities and intentionality of the managers of the firms in that society to environmental management implementations will increase.

H7: There is a positive relationship between the public environmental sensitivity and the intention of managers to implement environmental management.

\section{Environmental Sensitivity of Managers}

The environmental sensitivity of managers expresses the sensitivity of managers as individuals concerning environmental issues. Increase of sensitivity increases the intentionality of managers to implement environmental management. In the literature, the following sub-titles were considered as obstacles to environmental management implementation of managers: Not highlighting environmental issues (Clausen et al., 2003; Delmas and Toffel, 2004; Hamner, 2005; Pfeffer, 2005; Wagner and Schaltegger, 2004). Not supporting environmental causes (Wagner and Schaltegger 2004). Not having spare time for environmental issues (Clausen et al., 2003). Not having faith in benefits arising from environmental enterprises (Clausen et al., 2003). Placing more importance to making profit than to protect the environment (Martin, 2005; Pfeffer, 2005; Wagner and Schaltegger, 2004). Not believing that environmental harms is the most important problem that the society confronts (Martin, 2005; Pfeffer, 2005; Wagner and Schaltegger, 2004).. Thus, with the effect of environmental sensitivity, the intentionality of managers of such firms to environmental management implementations will increase.

H8: There is a positive relationship between the environmental sensitivity of managers and intention of managers to implement environmental management.

\section{External Uncertainty}

External uncertainty expresses the predictability of activities of the close neighboring external to the firm, the national periphery and the international periphery. As predictability increases, increases the intentionality of managers to environmental management implementations. In previous studies, in determination of the external uncertainty level, the predictability level of the following activities are pointed out: Activities of suppliers, customer demands, tastes and preferences, market activities of competitors, removing restrictive requirements and globalization, state regulations and policies, economic periphery, business relations, product technologies and information technologies. (Albino et al., 2009; Brammer and Pavelin, 2008; Chiang and Tseng, 2005; Claver et al. , 2007; Curcio and Wolf, 1996; Çakmak, 2007; Henri and Journeault, 2008a; Hoffman, 2000; Hontou et al., 2007; Orsato, 2006; Sarmentoa et al., 2007; Wagner and Schaltegger, 2004). Thus, with the effect of external uncertainty, the environmental sensitivity and intentionality to environmental management implementations of managers in the atmosphere where external uncertainty is experienced will increase.

H9: There is a positive relationship between external uncertainty and intention of managers to implement environmental management. 


\section{RESEARCH MODEL}

Research model is given below:

\begin{tabular}{|c|c|}
\hline $\begin{array}{l}\text { The antecedents perceived by managers as premi- } \\
\text { ses that direct firms to environmental management } \\
\text { (Independent variables) }\end{array}$ & $\begin{array}{l}\text { Intention of managers to implement environmen- } \\
\text { tal management }\end{array}$ \\
\hline & $\begin{array}{l}\text { The importance attached to the measurement of the } \\
\text { general environmental performance indicators }\end{array}$ \\
\hline \multicolumn{2}{|l|}{ National environmental characteristics } \\
\hline Stakeholder pressures & $\begin{array}{l}\text { The importance attached to the measurement of the } \\
\text { specific environmental performance indicators }\end{array}$ \\
\hline \multicolumn{2}{|l|}{ Eco-efficiency rates } \\
\hline Firm's past performance & Use of environmental performance indicators \\
\hline \multicolumn{2}{|l|}{ Strategic priority } \\
\hline Customer environmental sensitivity & Environmental budget-related activities \\
\hline Public environmental sensitivity & $\begin{array}{l}\text { Integration of environmental performance indicators } \\
\text { in employee evaluation }\end{array}$ \\
\hline \multicolumn{2}{|l|}{ Environmental sensitivity of managers } \\
\hline External uncertainty & Environmental strategic planning and management \\
\hline
\end{tabular}

\section{RESEARCH DESIGN}

The questionnaire data were gathered from firm managers in the Turkish Construction Sector by e-mail, telephone, and face-to-face interviews. An important part, approximately $90 \%$ of the sampling set consists of managers in large and medium scale firms, selected randomly. The number of usable questionnaires is 202.

All scales in the study ( $1=\mathrm{I}$ absolutely disagree; $5=\mathrm{I}$ absolutely agree) are measured using 5 Likert type scales. Out of 9 antecedents perceived by managers as premises that direct firms to environmental management, 3 have been adapted from previous studies. These are stakeholder pressures, strategic priority and external uncertainty. For stakeholder pressures, the Buysse and Verbeke (2003) scale composed of 16 components has been used. Strategic priority has been measured using Aytekin (2003) scale composed of 5 components, plus an additional "energy and environment" component, making 6 components in total. For external uncertainty, the Henri and Journeault (2008a) scale composed of 9 components has been used. Out of 9 antecedents perceived by managers as premises that direct firms to environmental management, 6 antecedents have not been adapted from previous studies. National environmental characteristics, ecoefficiency rates, the firm's past performance, customers environmental sensitivity, public environmental sensitivity and environmental sensitivity of managers were not directly taken from previous studies, but were established independently, taking the references mentioned in the literature review section.

The 6 sub-titles and the scales used in measuring the intention of managers to implement environmental management are as follows: The importance attached to the measurement of general and special environmental performance indicators was measured by a scale developed by Henri and Journeault (2008a) and consisting of 13 factors, based on the ISO 14031 standard which is a sub-category of IS0 14001. Use of environmental performance indicators was measured by combining 2 scales, one developed by Bennett $\&$ James (1998) and consisting of 4 factors and the other developed by Henri and Journeault (2008a) and consisting of 3 factors. Environmental budget activities was measured by a scale developed by Henri and Journeault (2008a) and consisting of 4 factors. Use of environmental performance indicators in employee evaluation was measured by a scale developed by Sharma (2000) and consisting of 3 factors. Environmental strategic planning and management systems was measured by combining 2 scales, one developed by Judge and Douglas (1998) to measure environmental strategic planning and consisting of 4 factors, and the other developed by Melnyk et al. (2003) and consisting of 2 factors. 
In this study, to test the hyphotheses the following analyses were conducted: factor analyses, reliability tests, mean and standard deviation values, correlation analyses and regression analyses. And the findings will be discussed.

\section{DATA ANALYSIS AND HYPOTHESES TEST RESULTS}

First, the frequency tables for the managers and the firms that had provided responses to the survey and then the tables for the descriptive statistics were prepared.

35 questions were asked to determine the intention of managers to implement environmental management and total six factors were established as a result of factor analysis. The factors loads were found to be quite satisfactory and the total variance defined by the 6 variables resulted as $69.68 \%$.

51 questions were asked to determine the antecedents perceived by managers as premises that direct firms to environmental management and seven factors in total were established as a result of factor analysis. The factor loads were found to be quite satisfactory and the total variance defined by the 7 variables resulted as $62 \%$.

After analyzing the survey questions used in the research, reliabilities for the variables perceived by managers as antecedents that lead firms to environmental management and the items of the intention of managers to implement environmental management were controlled. Cronbach alpha coefficients were then calculated for each item. This coefficient varies between 0-1 and values below 0.6 define unsatisfactory internal consistency (Malhotra quotation from Aytekin 2003, 1993, p.308). All of the Cronbach alpha coefficients were higher than 0.75 which meant an acceptable level for the organizational researches.

The Table I gives the correlation matrix. This table shows the correlations between the variables perceived by managers as antecedents that lead firms to environmental management and the variables concerning the intention of managers to implement environmental management.

When the table is analyzed, one can see that statistically significant correlations among almost all variables, except for strategic priority and customer environmental sensitivity, are noteworthy. There is a positive and 2-tailed correlation at the level of 0,05 among such variables which exhibit statistically significant correlations. There is a positive and 2-tailed correlation at the level of 0.01 between the public environmental sensitivity and the eco-efficiency rates as two of the independent variables in the model. However there is no correlation between firm's past performance as one of the independent variables and importance attached to the measurement of the general and specific environmental performance indicators as two of dependent variables. There is no correlation between customer environmental sensitivity and national environmental characteristics, eco-efficiency rates, strategic priority, importance attached to the measurement of the general environmental performance indicators, importance attached to the measurement of the specific environmental performance indicators and environmental strategic planning and management. There is no correlation between strategic priority as one of the independent variables and all other variables.

The influence of the variables perceived by managers as antecedents that lead firms to environmental management on the variables concerning the intention of managers to implement environmental management was also examined by means of regression analyses. In the below tables, concise information is provided on the hypotheses, standardized Beta coefficients ( $($ ), p-value (signifance) and acceptance or rejection status of the hypotheses. 
Journal of Global Strategic Management | V. 5 | N. 1 | 2011-June | isma.info | 157-174 | DOI:10.20460/JGSM.2011515820

Table 1. Correlation matrix for variables

\begin{tabular}{|c|c|c|c|c|c|c|c|c|c|c|c|c|c|c|}
\hline Variable & 1 & 2 & 3 & 4 & 5 & 6 & 7 & 8 & 9 & 10 & 11 & 12 & 13 & 14 \\
\hline \multicolumn{15}{|l|}{$\begin{array}{l}\text { 1. National } \\
\text { environmental } \\
\text { characteristics }\end{array}$} \\
\hline $\begin{array}{l}\text { 2. Stakeholder } \\
\text { pressures }\end{array}$ &, $454^{* * *}$ & & & & & & & & & & & & & \\
\hline 3. Eco-efficiency rates &, $370^{* * *}$ &, $428 * *$ & & & & & & & & & & & & \\
\hline $\begin{array}{l}\text { 4. The firm's past } \\
\text { performance }\end{array}$ &, $201 * *$ &, $221 * *$ & $\begin{array}{c}244 * \\
*\end{array}$ & & & & & & & & & & & \\
\hline 5. Strategic priority &,- 023 & $\begin{array}{l}-079 \\
-, 9\end{array}$ & ,000 &,- 038 & & & & & & & & & & \\
\hline $\begin{array}{l}\text { 6. Customer } \\
\text { environmental } \\
\text { sensitivity }\end{array}$ & 035 &, $237^{* *} *$ &, 060 & $\underset{*}{2223 *}$ &,- 133 & & & & & & & & & \\
\hline $\begin{array}{l}\text { 7. The public } \\
\text { environmental } \\
\text { sensitivity }\end{array}$ &, $234 * *$ &, $191^{* *}$ &, $180^{*}$ & $\begin{array}{c}, 276^{*} \\
*\end{array}$ & ,041 &, $194 * *$ & & & & & & & & \\
\hline $\begin{array}{l}\text { 8. The environmental } \\
\text { sensitivity of } \\
\text { managers }\end{array}$ &, $305^{* *}$ &, $285^{* *}$ & $\begin{array}{c}, 201 * \\
*\end{array}$ & $\underset{*}{, 314^{*}}$ &, 019 &, $337 * *$ &, $638^{* *}$ & & & & & & & \\
\hline 9. External uncertainty &, $258^{* *}$ &, $256^{* *}$ & $\begin{array}{c}190^{*} \\
*\end{array}$ & $\begin{array}{c}318^{*} \\
*\end{array}$ &, 002 &, $322 * *$ &, $354 * *$ &, $512 * *$ & & & & & & \\
\hline $\begin{array}{l}\text { 10. The importance } \\
\text { attached to the } \\
\text { measurement of the } \\
\text { general environmental } \\
\text { performance } \\
\text { indicators }\end{array}$ &, $374 * *$ &, $262 * *$ & $\begin{array}{c}399 * \\
*\end{array}$ & , 130 &,- 051 & 091 &, $464 * *$ &, $458 * *$ &, $353^{* * *}$ & & & & & \\
\hline $\begin{array}{l}\text { 11. The importance } \\
\text { attached to the } \\
\text { measurement of the } \\
\text { specific environmental } \\
\text { performance } \\
\text { indicators }\end{array}$ &, $282 * *$ &, $201 * *$ & $\begin{array}{c}325^{*} \\
*\end{array}$ & ,084 &,- 050 & ,082 &, $306 * *$ &, $361^{* *}$ &, $307^{* * *}$ &, $671 * *$ & & & & \\
\hline $\begin{array}{l}\text { 12. Use of } \\
\text { environmental } \\
\text { performance } \\
\text { indicators }\end{array}$ &, $428^{* * *}$ &, $336 * *$ & $\begin{array}{c}, 393^{*} \\
*\end{array}$ &, $219^{*}$ &,- 054 &, $154^{*}$ &, $419 * *$ &, $533 * *$ &, $458^{* *}$ &, $694 * *$ &, $633 * *$ & & & \\
\hline $\begin{array}{l}\text { 13. Environmental } \\
\text { budget-related } \\
\text { activities }\end{array}$ &, $351^{* *}$ &, $267 * *$ &, $255^{*}$ & , $230^{*}$ &,- 096 &, $186 * *$ &, $315^{* *}$ &, $387 * *$ &, $395^{* * *}$ &, $409^{* * *}$ &, $334 * *$ &, $425 * *$ & & \\
\hline $\begin{array}{l}\text { 14. Integration of } \\
\text { environmental } \\
\text { performance } \\
\text { indicators in employee } \\
\text { evaluation }\end{array}$ &, $313^{* * *}$ &, $241 * *$ & $\begin{array}{c}, 307 * \\
*\end{array}$ & $\underset{*}{, 195^{*}}$ &,- 084 &, $144 *$ &, $239 * *$ &, $416^{* * *}$ &, $429 * *$ &, $537 * *$ &, $478^{* * *}$ &, $673 * *$ &, $395^{* * *}$ & \\
\hline $\begin{array}{l}\text { 15. Environmental } \\
\text { strategic planning and } \\
\text { management }\end{array}$ &, $358^{* * *}$ &, $334 * *$ & $\begin{array}{c}357^{*} \\
*\end{array}$ &, $184 *$ & ,005 &, 116 &, $367 * *$ &, $502 * *$ &, $428^{* *}$ &, $612^{* * *}$ &, $593 * *$ &, $732 * *$ &, $480^{* * *}$ & $\begin{array}{c}, 661^{*} \\
*\end{array}$ \\
\hline
\end{tabular}

$\mathrm{n}=202$

** Correlation is significant at the 0.01 level (2-tailed).

* Correlation is significant at the 0.05 level (2-tailed). 
Journal of Global Strategic Management | V. 5 | N. 1 | 2011-June | isma.info | 157-174 | DOI:10.20460/JGSM.2011515820

\begin{tabular}{|c|l|c|c|l|}
\hline No & \multicolumn{1}{|c|}{ Hypotheses } & $\boldsymbol{\beta}$ & p & \multicolumn{1}{|c|}{ Result } \\
\hline 1 & $\begin{array}{l}\text { There is a positive relationship between the national environmental characteristics } \\
\text { and the variables given below. }\end{array}$ & Accept & & \\
\hline 1-a & $\begin{array}{l}\text { The importance attached to the measurement of the general environmental per- } \\
\text { formance indicators }\end{array}$ &, 156 &, 020 & Accept \\
\hline 1-b & $\begin{array}{l}\text { The importance attached to the measurement of the specific environmental per- } \\
\text { formance indicators }\end{array}$ &, 108 &, 151 & Reject \\
\hline 1-c & Use of environmental performance indicators &, 182 &, 005 & Accept \\
\hline 1-d & Environmental budget-related activities &, 187 &, 011 & Accept \\
\hline 1-e & Integration of environmental performance indicators in employee evaluation &, 119 &, 098 & Reject \\
\hline 1-f & Environmental strategic planning and management &, 100 &, 142 & Reject \\
\hline
\end{tabular}

ß: Standardized Beta Coefficients; p: p-value (Signifance)

In the above table, the results of the regression analysis indicating the relationship between the national environmental characteristics as one of the independent variables perceived by managers as antecedents that lead firms to environmental management and the dependent variables concerning the intention of managers to implement environmental management is given.

In the research model, positive relationship was found at the level of 0.01 between the national environmental characteristics as one of the independent variables and the use of environmental performance indicators as one of the dependent variables. In the research model, positive relationship was found at the level of 0.05 between the national environmental characteristics as one of the independent variables and the importance attached to the measurement of the general environmental performance indicators and environmental budget-related activities as dependent variables. However there is no positive relationship between the national environmental characteristics as one of the independent variables in the model and other dependent variables. According to these results, the hypothesis stating that there is a positive relationship between the national en vironmental characteristics and the intention of managers to implement environmental management must be accepted.

\begin{tabular}{|c|l|c|c|l|}
\hline No & \multicolumn{1}{|c|}{ Hypotheses } & $\boldsymbol{\beta}$ & \multicolumn{1}{|c|}{ p } & \multicolumn{1}{|c|}{ Result } \\
\hline 2 & $\begin{array}{l}\text { There is a positive relationship between stakeholder pressures and the variables } \\
\text { given below. }\end{array}$ & Reject & & Reject \\
\hline 2-a & $\begin{array}{l}\text { The importance attached to the measurement of the general environmental perform- } \\
\text { ance indicators }\end{array}$ &,- 030 &, 664 \\
\hline 2-b & $\begin{array}{l}\text { The importance attached to the measurement of the specific environmental per- } \\
\text { formance indicators }\end{array}$ &,- 037 &, 632 & Reject \\
\hline 2-c & Use of environmental performance indicators &, 023 &, 721 & Reject \\
\hline 2-d & Environmental budget-related activities &, 018 &, 809 & Reject \\
\hline 2-e & Integration of environmental performance indicators in employee evaluation &,- 020 &, 782 & Reject \\
\hline 2-f & Environmental strategic planning and management &, 087 &, 214 & Reject \\
\hline
\end{tabular}

\section{ß: Standardized Beta Coefficients; $\mathrm{p}$ : p-value (Signifance)}

In the above table, the results of the regression analysis indicating the relationship between stakeholder pressures as one of the independent variables perceived by managers as antecedents that lead firms to environmental management and the dependent variables concerning the intention of managers to implement environmental management is given.

There is no positive relationship between stakeholder pressures as one of the independent variables in the model and other dependent variables. According to these results, the hypothesis stating that there is a positive relationship between stakeholder pressures and the intention of managers to implement environmental management can be accepted. 
Journal of Global Strategic Management | V. 5 | N. 1 | 2011-June | isma.info | 157-174 | DOI:10.20460/JGSM.2011515820

\begin{tabular}{|c|l|c|c|l|}
\hline No & \multicolumn{1}{|c|}{ Hypotheses } & $\boldsymbol{\beta}$ & \multicolumn{1}{|c|}{ p } & \multicolumn{1}{|c|}{ Result } \\
\hline 3 & $\begin{array}{l}\text { There is a positive relationship between the eco-efficiency rates and the variables } \\
\text { given below. }\end{array}$ & Accept & & Accept \\
\hline 3-a & $\begin{array}{l}\text { The importance attached to the measurement of the general environmental perform- } \\
\text { ance indicators }\end{array}$ &, 278 &, 000 & Accept \\
\hline 3-b & $\begin{array}{l}\text { The importance attached to the measurement of the specific environmental per- } \\
\text { formance indicators }\end{array}$ &, 245 &, 000 & Ac \\
\hline 3-c & Use of environmental performance indicators &, 215 &, 001 & Accept \\
\hline 3-d & Environmental budget-related activities &, 088 &, 214 & Reject \\
\hline 3-e & Integration of environmental performance indicators in employee evaluation &, 184 &, 009 & Accept \\
\hline 3-f & Environmental strategic planning and management &, 191 &, 004 & Accept \\
\hline
\end{tabular}

B: Standardized Beta Coefficients; p: p-value (Signifance)

In the above table, the results of the regression analysis indicating the relationship between the ecoefficiency rates as one of the independent variables perceived by managers as antecedents that lead firms to environmental management and the dependent variables concerning the intention of managers to implement environmental management is given.

In the research model, positive relationship was found at the level of 0.01 between the eco-efficiency rates as one of the independent variables and the importance attached to the measurement of the general environmental performance indicators, the importance attached to the measurement of the specific environmental performance indicators, use of environmental performance indicators, integration of environmental performance indicators in employee evaluation and environmental strategic planning and management as dependent variables. However there is no positive relationship between the eco-efficiency rates as one of the independent variables in the model and environmental budget-related activities as one of the dependent variables. According to these results, the hypothesis stating that there is a positive relationship between the eco-efficiency rates and the intention of managers to implement environmental management must be accepted.

\begin{tabular}{|c|l|c|c|l|}
\hline No & \multicolumn{1}{|c|}{ Hypotheses } & $\boldsymbol{1}$ & \multicolumn{1}{|c|}{ p } & \multicolumn{1}{|c|}{ Result } \\
\hline 4 & $\begin{array}{l}\text { There is a positive relationship between the firm's past performance and the vari- } \\
\text { ables given below. }\end{array}$ & Accept & & Accept \\
\hline 4-a & $\begin{array}{l}\text { The importance attached to the measurement of the general environmental perform- } \\
\text { ance indicators }\end{array}$ &,- 127 &, 041 \\
\hline 4-b & $\begin{array}{l}\text { The importance attached to the measurement of the specific environmental per- } \\
\text { formance indicators }\end{array}$ &,- 123 &, 077 & Reject \\
\hline 4-c & Use of environmental performance indicators &,- 053 &, 375 & Reject \\
\hline 4-d & Environmental budget-related activities &, 027 &, 696 & Reject \\
\hline 4-e & Integration of environmental performance indicators in employee evaluation &,- 017 &, 800 & Reject \\
\hline 4-f & Environmental strategic planning and management &,- 063 &, 313 & Reject \\
\hline
\end{tabular}

B: Standardized Beta Coefficients; p: p-value (Signifance)

In the above table, the results of the regression analysis indicating the relationship between the firm's past performance as one of the independent variables perceived by managers as antecedents that lead firms to environmental management and the dependent variables concerning the intention of managers to implement environmental management is given.

In the research model, positive relationship was found at the level of 0.05 between the firm's past performance as one of the independent variables and the importance attached to the measurement of the general environmental performance indicators as one of the dependent variables. However there is no positive relationship between the eco-efficiency rates as one of the independent variables in the model and other dependent variables. According to these results, the hypothesis stating that there is a positive relationship between the firm's past performance and the intention of managers to implement environmental management must be accepted. 
Journal of Global Strategic Management | V. 5 | N. 1 | 2011-June | isma.info | 157-174 | DOI:10.20460/JGSM.2011515820

\begin{tabular}{|c|l|c|c|l|}
\hline No & \multicolumn{1}{|c|}{ Hypotheses } & $\boldsymbol{1}$ & \multicolumn{1}{|c|}{ p } & \multicolumn{1}{|c|}{ Result } \\
\hline 5 & $\begin{array}{l}\text { There is a positive relationship between strategic priority and the variables given } \\
\text { below. }\end{array}$ & Reject & & Reject \\
\hline 5-a & $\begin{array}{l}\text { The importance attached to the measurement of the general environmental perform- } \\
\text { ance indicators }\end{array}$ &,- 078 &, 170 \\
\hline 5-b & $\begin{array}{l}\text { The importance attached to the measurement of the specific environmental per- } \\
\text { formance indicators }\end{array}$ &,- 070 &, 276 & Reject \\
\hline 5-c & Use of environmental performance indicators &,- 066 &, 224 & Reject \\
\hline 5-d & Environmental budget-related activities &,- 093 &, 139 & Reject \\
\hline 5-e & Integration of environmental performance indicators in employee evaluation &,- 092 &, 134 & Reject \\
\hline 5-f & Environmental strategic planning and management &,- 009 &, 879 & Reject \\
\hline
\end{tabular}

ß: Standardized Beta Coefficients; p: p-value (Signifance)

In the above table, the results of the regression analysis indicating the relationship between strategic priority as one of the independent variables perceived by managers as antecedents that lead firms to environmental management and the dependent variables concerning the intention of managers to implement environmental management is given.

There is no positive relationship between strategic priority as one of the independent variables in the model and other dependent variables. According to these results, the hypothesis stating that there is a positive relationship between strategic priority and the intention of managers to implement environmental management can be accepted.

\begin{tabular}{|c|l|c|c|l|}
\hline No & \multicolumn{1}{|c|}{ Hypotheses } & $\boldsymbol{\beta}$ & \multicolumn{1}{|c|}{ p } & \multicolumn{1}{|c|}{ Result } \\
\hline 6 & $\begin{array}{l}\text { There is a positive relationship between customer environmental sensitivity and the } \\
\text { variables given below. }\end{array}$ & Reject & & Reject \\
\hline 6-a & $\begin{array}{l}\text { The importance attached to the measurement of the general environmental perform- } \\
\text { ance indicators }\end{array}$ &,- 066 &, 294 \\
\hline 6-b & $\begin{array}{l}\text { The importance attached to the measurement of the specific environmental per- } \\
\text { formance indicators }\end{array}$ &,- 047 &, 506 & Reject \\
\hline 6-c & Use of environmental performance indicators &,- 054 &, 371 & Reject \\
\hline 6-d & Environmental budget-related activities &, 022 &, 747 & Reject \\
\hline 6-e & Integration of environmental performance indicators in employee evaluation &,- 042 &, 535 & Reject \\
\hline 6-f & Environmental strategic planning and management &,- 093 &, 147 & Reject \\
\hline
\end{tabular}

\section{ß: Standardized Beta Coefficients; $\mathrm{p}$ : p-value (Signifance)}

In the above table, the results of the regression analysis indicating the relationship between customer environmental sensitivity as one of the independent variables perceived by managers as antecedents that lead firms to environmental management and the dependent variables concerning the intention of managers to implement environmental management is given.

There is no positive relationship between customer environmental sensitivity as one of the independent variables in the model and other dependent variables. According to these results, the hypothesis stating that

\begin{tabular}{|c|c|c|c|c|}
\hline No & Hypotheses & $\beta$ & $\mathbf{p}$ & Result \\
\hline 7 & $\begin{array}{l}\text { There is a positive relationship between the public environmental sensitivity and } \\
\text { the variables given below. }\end{array}$ & Accept & & \\
\hline $7-\mathrm{a}$ & $\begin{array}{l}\text { The importance attached to the measurement of the general environmental perform- } \\
\text { ance indicators }\end{array}$ &, 267 &, 000 & Accept \\
\hline $7-b$ & $\begin{array}{l}\text { The importance attached to the measurement of the specific environmental per- } \\
\text { formance indicators }\end{array}$ &, 109 &, 185 & Reject \\
\hline $7-c$ & Use of environmental performance indicators & ,099 &, 160 & Reject \\
\hline $7-d$ & Environmental budget-related activities & ,088 &, 279 & Reject \\
\hline 7 -e & Integration of environmental performance indicators in employee evaluation &,- 076 & ,334 & Reject \\
\hline $7-f$ & Environmental strategic planning and management &, 049 & 511 & Reject \\
\hline
\end{tabular}


there is a positive relationship between customer environmental sensitivity and the intention of managers to implement environmental management must be accepted.

\section{B: Standardized Beta Coefficients; p: p-value (Signifance)}

In the above table, the results of the regression analysis indicating the relationship between the public environmental sensitivity as one of the independent variables perceived by managers as antecedents that lead firms to environmental management and the dependent variables concerning the intention of managers to implement environmental management is given.

In the research model, positive relationship was found at the level of 0.01 between the public environmental sensitivity as one of the independent variables and the importance attached to the measurement of the general environmental performance indicators as one of the dependent variables. However there is no positive relationship between the public environmental sensitivity as one of the independent variables in the model and other dependent variables. According to these results, the hypothesis stating that there is a positive relationship between the public environmental sensitivity and the intention of managers to implement environmental management must be accepted.

\begin{tabular}{|c|c|c|c|c|}
\hline No & Hypotheses & $\boldsymbol{\beta}$ & $\mathbf{p}$ & Result \\
\hline 8 & $\begin{array}{l}\text { There is a positive relationship between the environmental sensitivity of managers } \\
\text { and the variables given below. }\end{array}$ & Accept & & \\
\hline $8-\mathrm{a}$ & $\begin{array}{l}\text { The importance attached to the measurement of the general environmental perform- } \\
\text { ance indicators }\end{array}$ &, 185 & ,025 & Accept \\
\hline $8-\mathrm{b}$ & $\begin{array}{l}\text { The importance attached to the measurement of the specific environmental per- } \\
\text { formance indicators }\end{array}$ & ,194 & ,036 & Accept \\
\hline $8-\mathrm{c}$ & Use of environmental performance indicators & ,291 &, 000 & Accept \\
\hline 8 -d & Environmental budget-related activities &, 127 &, 162 & Accept \\
\hline $8-e$ & Integration of environmental performance indicators in employee evaluation & ,280 & ,002 & Accept \\
\hline $8-f$ & Environmental strategic planning and management &, 320 &, 000 & Accept \\
\hline
\end{tabular}

ß: Standardized Beta Coefficients; $\mathrm{p}$ : p-value (Signifance)

In the above table, the results of the regression analysis indicating the relationship between the environmental sensitivity of managers as one of the independent variables perceived by managers as antecedents that lead firms to environmental management and the dependent variables concerning the intention of managers to implement environmental management is given.

In the research model, positive relationship was found at the level of 0.01 between the environmental sensitivity of managers as one of the independent variables and the use of environmental performance indicators, integration of environmental performance indicators in employee evaluation and environmental strategic planning and management as dependent variables. In the research model, positive relationship was found at the level of 0.05 between the environmental sensitivity of managers as one of the independent variables and the importance attached to the measurement of the general environmental performance indicators, the importance attached to the measurement of the specific environmental performance indicators and environmental budget-related activities as dependent variables. According to these results, the hypothesis stating that there is a positive relationship between the environmental sensitivity of managers and the intention of managers to implement environmental management must be accepted.

\begin{tabular}{|c|l|c|c|l|}
\hline No & \multicolumn{1}{|c|}{ Hypotheses } & $\boldsymbol{1}$ & \multicolumn{1}{|c|}{ p } & \multicolumn{1}{|c|}{ Result } \\
\hline 9 & $\begin{array}{l}\text { There is a positive relationship between the external uncertainty and the variables } \\
\text { given below. }\end{array}$ & Accept & & Accept \\
\hline 9-a & $\begin{array}{l}\text { The importance attached to the measurement of the general environmental perform- } \\
\text { ance indicators }\end{array}$ &, 140 &, 040 & Accept \\
\hline 9-b & $\begin{array}{l}\text { The importance attached to the measurement of the specific environmental per- } \\
\text { formance indicators }\end{array}$ &, 158 &, 039 & Act \\
\hline 9-c & Use of environmental performance indicators &, 214 &, 001 & Accept \\
\hline 9-d & Environmental budget-related activities &, 214 &, 005 & Accept \\
\hline 9-e & Integration of environmental performance indicators in employee evaluation &, 272 &, 000 & Accept \\
\hline 9-f & Environmental strategic planning and management &, 213 &, 002 & Accept \\
\hline
\end{tabular}

B: Standardized Beta Coefficients; p: p-value (Signifance) 
In the above table, the results of the regression analysis indicating the relationship between the external uncertainty as one of the independent variables perceived by managers as antecedents that lead firms to environmental management and the dependent variables concerning the intention of managers to implement environmental management is given.

In the research model, positive relationship was found at the level of 0.01 between the external uncertainty as one of the independent variables and the use of environmental performance indicators, environmental budget-related activities, integration of environmental performance indicators in employee evaluation and environmental strategic planning and management as dependent variables. In the research model, positive relationship was found at the level of 0.05 between the external uncertainty as one of the independent variables and the importance attached to the measurement of the general environmental performance indicators, the importance attached to the measurement of the specific environmental performance as dependent variables. According to these results, the hypothesis stating that there is a positive relationship between the external uncertainty and the intention of managers to implement environmental management must be accepted.

\section{MANAGERIAL IMPLICATIONS}

In this study, the variables perceived by the managers of the Turkish construction sector as antecedents that lead firms to environmental management are explained. In fact, these should not be the sole antecedents that would lead the managers to environmental management; therefore the managers should try to develop sensitivity and awareness to the environmental issues by taking into account the below factors:

Although information spreads fast and efficiently and products and services are quickly copied by the competitors, ideas are paradoxically slow in dissemination. The organizations are administrated not according to new ideas, business models (6 sigma, delegation, employee loyalty) and management approaches but according to the thinking, perceptions and experiences of their managers. Very much like different ideas forming different thinking trends, different thinking trends support different organizational performances. For example, there are many evidences indicating that increased focus on financial responsibility is preventing the discovery of errors in the companies (Pfeffer, 2005). Companies sharing same strategies understand the errors in their thinking when they see the success of their competitors but having different strategies (Walsh, 2007). Therefore development of long term strategies about environmental matters is very important since it will emerge as a strong competition tool in the near future although it is not sufficiently understood today very much like the quality issue that was neither understood in the past. Sustainable development, competition and environmental performance do not actually present a dilemma; rather than that, they will positively affect each other in the coming period. If the companies decide to include environmental costs in their operational costs, new targets such as reduction of wastes may be added to the standard goals such as profitability and for that purpose, the enterprises should be supported in carrying on their business activities in line with the requirements of sustainable development. It must be understood that the enterprises are socially responsible toward their employees, customers and society and that they can capture new markets and gain competitive advantages by protecting the natural environment. Any missing activities determined for the government and industrial sector concerning en vironmental protection should be pointed out and the social expectations regarding environmental management and sustainable development should be met at the highest level.

\section{FUTURE RESEARCH IMPLICATIONS}

If we want to look at the implementation of environmental management in the sector or sectors other than the construction sector in Turkey, then we must add more questions to survey in relation to the variables specific for that sector or sectors. The increasing percentage of the energy costs in the sector within the total production cost will naturally support the interest to be given to that issue in that sector. When a firm increases its business volume, it will be more interested toward the implementation of environmental management and therefore this implementation will give different results in case of SMEs and in case of big firms. This study may be also applied in other countries in addition to Turkey. Nevertheless environmental sensitivity of customers and stakeholder pressures are the antecedents that should be considered as the antecedents leading firms to environmental management by the managers in the future researches.

Other firm antecedents that could be considered in the future research are the firm's age, its ownership structure, its origin, main production activity, main product market, whether firm is a multinational or not, its independence status, number of employees, turnover, existence of an environmental department. Finally antecedents for managers are their gender, age, environmental occupation, their environmental work experience, position in the firm and their tenure of service in the firm. 


\section{CONCLUSION}

As a result of this study applied in the Turkish construction sector in 2010 , it was determined that the variables perceived by the managers of the construction sector as antecedents that lead firms to environmental management are national environmental characteristics, eco-efficiency rates, firm's past performance, public environmental sensitivity, environmental sensitivity of the managers and external uncertainty. The results of the study indicate that all 6 hypotheses were accepted. Accordingly, it was proven that there is a positive relationship between the national environmental characteristics, eco-efficiency rates, firm's past performance, public environmental sensitivity, environmental sensitivity of the managers and external uncertainty which are variables perceived by the managers as the antecedents that lead firms to environmental management and the intention of managers to implement environmental management. This result supports the similar studies in the literature referenced in the section on the factors influencing intention of managers to implement environmental management.

Today the impacts of environmental problems quickly spread in the world and affect all people, countries and the firms at the same time. The implementation of environmental management by the firms is important due to the reasons detailed below for the common benefit of humanity, countries and the firms:

If we examine this issue from the point of view of humanity, we see that environmental problems were understood to be at global level since 1960s. The United Nations started to show keen interest to environmental issues around the same date. The air pollution experienced in 1952 and 1966 in London and New York, mortal mercury poisoning in the Minamata and Nigata of Japan between 1953 and 1965, collective death of birds in some lakes of the Northern America and diseases and death incidents caused by DDT or other pesticides and similar events showed that the dilemma of environmental problems and general development must be absolutely solved by the authorities. In the process starting from October 1984 and ending on April 1987 when the World Environment and Development Commission that was assigned in 1983 by the BM Secretary General to prepare the global agenda of change started to conduct its studies, the scope of the environmental crises expanded considerably. A leakage from the agricultural medicines plant in the Bhopal region of India caused the death of more than 2.000 people and also made more than 200.000 people blind or injured. The explosion in the Chernobyl Nuclear Power Plant disseminated nuclear radiation throughout Europe and became a strong factor in increasing the cancer risk in the future. As a result of "domino effect" resulting from the dissemination of toxic materials in the air, water and earth such as the dissemination resulting from an explosion in the ammonium nitrate fertilizer plant in the Toulouse city of France during September o1 2001, the environmental impacts may get much stronger. The big environmental crises experienced in the world showed that environmental problems know no limits. Thus the importance of cooperation and solidarity at international level is now easily understood and it is known that national states may not be powerful enough to solve the environmental pollution problems spreading beyond their borders although the state approach is the most important factor in the protection of environment. It shall be also the responsibility of companies and organizations to be attentive to environmental pollution whether it arises at local level or at global level (Yontar, 2008). Therefore it should be the common target of all humanity to protect the natural environment and provide our children a sustainable future.

The countries are also giving importance to put barriers on the foreign dependency relating to the limited natural resources. The problems such as depletion of petroleum resources after 43 years, depletion of natural gas resources after 65 years, expected population increase from 6 billion in 1999 to 7 billion in 2012, CO2 emission per person and increase in the consumption of primary energy, i.e. increasing population, depleting natural resources and climatic changes are now forcing the countries to find alternative solutions. We will eventually understand whether the current situation poses a threat or opportunity after we evaluate the environmental management activities of the countries as far as they relate to the creation and protection of international firms and brands.

Especially the big firms in the developing countries are increasingly giving importance to the environmental management as they see it as a new competition strategy. The environmental management will surely become more important with the help of international conventions, pressures, regulations and standards. By 2019 all buildings in the Europe will be obligated to equalize the energy that they consume with the energy that they produce. It is planned to transform the average energy consumption to low energy and later to replace the existing houses with passive houses. The minimization of energy losses from a building and the reduction in the prices of the products depending on renewable energy with the help of developing technology will shorten the periods required for the return of investments relating to the renewable products although currently such investments have to be regarded as long term. The governmental incentives, tax benefits and privileged loan practices (loans with less than normal interest rates and longer terms) and the increasing environmental sensitivity of the customers will help to accelerate the return of investments which will be seen as economically reasonable. With the firms increasing their interest in the environmental protection and sensitivity, it will be much easier to develop different products and systems in order to penetrate into markets promising high profits.

Another important aspect of environmental management is the carbon trade for both countries and the firms. One of the most efficient mechanisms that will help us to transit to the low carbon economy by reducing the greenhouse gases emission in the struggle with the current climatic change is the carbon markets. The transaction volume of the global carbon market reached to Euro 90 billion in 2008 and Europe is responsible for the $80 \%$ of it. Since the carbon factor is re-defining the economic balances in the world, it will sooner or later start to affect business world and will bear important results (Kadilar, 2010)

Until now the as antecedents that lead firms to environmental management have served as the first ring to the relevant concepts discussed in the literature such as environmental strategy, environmental management, environmental performance, economic performance and organizational performance and they also helped to establish unity among all other antecedents that are seemingly disconnected and insufficient. 


\section{REFERENCES}

Albino, V., Balice, A., Dangelico, R. M., (2009), "Environmental Strategies and Green Product Development: an Overview on Sustainability-Driven Companies", Business Strategy and the Environment, 18, 83-96.

Arslan, K., (2010), “Eksen kayması”, Teori Dergisi, Temmuz 2010 Sayıs1, Sayfa:3-9

Aytekin M., "İmalat ve rekabet stratejileri arasındaki ilişki ve performansa etkileri”, GYTE Sosyal Bilimler Enstitüsü İşletme Fakültesi Doktora Tezi, 2003.

Barik, K., Pradhan, G., (1999), "Environment-Friendly Behaviour and Competitiveness: A Study of Pulp and Paper Industry in India", Environmental and Resource Economics, December, 14, 4, ABI/ INFORM Global, pg. 481.

Bekiroğlu, Ç., (2010), "Yeni Bir Rekabet Stratejisi: Enerji ve Çevre", IMSAD Sürdürülebilir Gündem Platformu, Sayı 2010/3.

Bonner, S., Hastie, R., Sprinkle, G., Young, S., (2000), "A review of the effects of financial incentives on performance in laboratory tasks: Implications for management accounting", Journal of Management Accounting Research, 12: 19-64.

Brammer, S., Pavelin, S., (2008), "Factors Influencing the Quality of Corporate Environmental Disclosure", Business Strategy and the Environment, 17, 120-136.

Chiang, J.H., Tseng, M.L., (2005), "The Impact of Environmental characteristic on Manufacturing Strategy under Cleaner Production Principles Guidance", Journal of American Academy of Business, Cambridge, September, 7, 1, ABI/INFORM Global, pg. 163.

Chinander, K., (2001), "Aligning accountability and awareness for environmental performance in operations", Production and Operations Management, 10(3): 276-291.

Claver, E., López, M. D., Molina, J. F., Tari, J. J., (2007), "Environmental management and firm performance: A case study”, Journal of Environmental Management, 84, 606-619.

Clausen, J., Hitchens, D., Keil, M., Thankappan, S., Trainor, M., (2003), "Competitiveness, Environmental Performance and Management of SMEs", Greener Management International, Winter, 44, ABI/INFORM Global pg. 45.

Curcio, R. J., Wolf, F. M., (1996), "Corporate Envirionmental Strategy: Impact Upon Firm Value”, Journal of Financial And Strategic Decisions, Volume 9, Number 2, Summer.

Çakmak, H., (2007), Türkiye'de Uygulanan Çevresel Vergilerin Eleştirel İncelenmesi, Yüksek Lisans (Master) Tezi, İstanbul: T.C. Maltepe Üniversitesi Sosyal Bilimler Enstitüsü İşletme Anabilim Dalı.

Delmas, M., Toffel, M. W., (2004), "Stakeholders and Environmental Management Practices: An Institutional Framework", Business Strategy and the Environment, 13, 209-222.

Denton, D.K., (1998), "Enviro-management as a profit center", Environmental Management and Health, Bradford, Vol. 9, Iss. 2, pg. 60.

Epstein, M., (1996), Measuring corporate environmental performance (McGraw-Hill, New York, NY).

Eren, E., (2003), Yönetim ve Organizasyon Kitabı, 6. Baskı, Yığışım Organizasyonlar, İstanbul, s.307 -320 .

Esinoğlu, B., (2010), "Enerji özelleştirmeleri ve ülke güvenliği”, Teori Dergisi, Temmuz 2010 Sayısı, Sayfa:10-11.

Esty, D.C., Porter, M., (2005), "National environmental performance: an empirical analysis of policy results and determinants", Environment and Development Economics, 10, 391-434 C, Cambridge University Pres.

Gabel, H. L., \& Sinclair-Desgagné, B., (1993), "Managerial incentives and environmental compliance", Journal of Environmental Economics and Management, 24, 229-40.

Hamans, C., (2009a), "Energy Efficiency in Buildings, Part 1 and 2", IMSAD EUbuild Binalarda Enerji Verimliliği Eğitimi, 1. Oturum 1. sunumu ve 2. Oturum 1. sunumu, 66 sunu dosyası, İstanbul: TOBB Plaza-Levent. 
Hamner, B., (2001), "Financing Cleaner Production", Working Paper, June 2001, CleanerProduction.Com/Hamner and Associates LLC.

Hamner, B., (2005), "Integrating Market-Based Sustainability Indicators and Performance Management Systems", Cleaner Production International, Seattle, Washington.

Hayes, R.H. and S.C. Wheelwright, (1984), "Restoring Our Competitive Edge", John Wiley and Sons, New York.

Henri, J.F., Journeault, M., (2008a), "Environmental performance indicators: An empirical study of Canadian manufacturing firms", Journal of Environmental Management, 87(1), 165-176.

Henri, J.F., Journeault, M., (2008b), "Eco-Efficiency and Organizational Practices: An Exploratory Study of Manufacturing Firms", École de Comptabilité, Université Laval.

Henri, J.F., Journeault, M., (2008c), "Eco-Control: The Influence of Management Control Systems on Environmental and Economic Performance", École de Comptabilité, Université Laval.

Hoffman, A. J., (2000), "Competitive Environmental Strategy: A Guide To The Changing Business Landscape", Island Press, 320 pages.

Hontou, V., Diakoulaki, D., Papagiannakis, L., (2007), "A Multicriterion Classification Approach for Assessing the Impact of Environmental Policies on the Competitiveness of Firms", Corporate Social Responsibility and Environmental Management, 14, 28-41.

Ilinitch, A., Soderstrom, N., Thomas, T., (1998), "Measuring corporate environmental performance", Journal of Accounting and Public Policy, 17(4,5): 383-408.

Judge, W., Douglas, T., (1998), "Performance Implications of Incorporating Natural Environmental Issues Into The Strategic Planning Process: An Empirical Assessment", The Journal of Management Studies, 35(2): 241-262.

Kadılar, R., (2010), “ Karbon Firsat mı, Tehdit mi?”, Destek Yayınevi: 91, Bilim:1, 1. Baskı, Eylül 2010.

Kent, R., (2008), "Energy Management in Plastics Processing: Strategies, targets, techniques and tools", Plastic Information Direct, First Edition.

Keskin, Ş., (2009), "Çevre Yönetim Sistemleri”, Imsad EUbuild Çevre Yönetimi Eğitimi , 1. Oturum 2. sunumu, 52 sunu dosyası, İstanbul: Kadir Has Üniversitesi, Kadir Has Kampüsü (Cibali) D BlokSinema A Salonu.

Künar, A., Santucci, D., Tatlıdamak, G., (2010), "Yüksek Performanslı "Sürdürülebilir Binalar" mı? Yoksa Yalnızca "Sertifikalı Binalar" mı?”, Yeşil Bina Sürdürülebilir Yapı Teknolojileri Dergisi, Temmuz-Ağustos 2010, s.50-52, Y11: 1/ Sayı:2.

Lothe, S., Myrtveit, I., Trapani, T., (1999), "Compensation systems for improving environmental performance", Business Strategy and the Environment, 8: 313-321.

Marshall, R.S., Brown, D., (2003), “ Corporate environmental reporting: what's in a metric?”, Business Strategy and the Environment, 12 (2), 87.

Martin B.A., (2005), "Creating value with proactive environmental strategies", Environmental Quality Management, Hoboken, Winter, Vol. 15, Iss. 2, pp. 21.

Mebratu, D., (2001), "Environmental Competitiveness "Green" Purchasing", International Trade Forum, Issue 2.

Melnyk, S., Sroufe, R., Calantone, R., (2003), "Assessing the impact of environmental management systems on corporate and environmental performance", Journal of Operations Management, 21(3): 329-351.

Orsato, R. J., (2006), "What Does It Pay To Be Gren", Competitive Environmental Strategies, California Management Review, Vol. 48, No.2, Winter.

Pfeffer, J., (2005), "Changing Mental Models: HR's Most Important Task", Human Resource Management, Summer, Vol. 44, No. 2, pg. 123-128.

Pringle, J., Lueteritz, K., Fitgerald, M., (1998), “ ISO 14001: a discussion of implications for pollution prevention”, National Pollution Prevention Roundtable, ISO 14000 Workgroup. 
Ramanujam, V., Venkatraman, N., Camillus, J., (1986), "Multi-Objective Assessment of Effectiveness of Strategic Planning: A Discriminant Analysis Approach", Academy of Management Journal, 29 (2): 347-372.

Sarmentoa, M., Dura ob, D., Duarteb, M., (2007), "Evaluation of company effectiveness in implementing environmental strategies for a sustainable development", Energy, 32, 920-926.

Smith, E., (2007), "IPCC Science Summary of its 4th Assessment Report", Business and the Environment.

Stead, W., Stead, J., (1995), "An Empirical Investigation of Sustainability Strategy Implementation in Industrial Organizations", Research in Corporate Social Performance and Policy Supplement, 1: 4366.

Teori, (2010), "Enerji, ekonomi ve güvenlik”, Temmuz 2010 Sayısı, Sayfa:2

TMMOB, (2009a), Dünyada ve Türkiye'de Eneri Verimliliği, Kocaeli: Türkiye Makine Mühendisleri Odası Yayınları, Gebze Tübitak II. Enerji Verimliliği Kongresi Oda Raporu Kitabı.

TMMOB, (2009b), Yeşiliyle, Mavisiyle Temiz Bir Dünya ve Herkese Sağlıklı, Güvenli Bir Yaşam İçin Günlük Yaşantımızda Enerji Tasarrufu Kılavuzu, Kocaeli: TMMOB Makine Mühendisleri Odası Yayınları, Gebze Tubitak II. Enerji Verimliliği Kongresi Kılavuz Kitapçığı.

TMMOB, (2009c), II. Enerji Verimliliği Kongresi Bildiriler Kitabı, Kocaeli: TMMOB Makine Mühendisleri Odası Yayınları, Tubitak, Gebze.

Türkyılmaz, O., (2010), "Enerjide çözüm: Ulusal strateji, ulusal kaynaklar, kamusal işletme”, Teori Dergisi, Temmuz 2010 Sayıs1, Sayfa:21-26.

Van Dierdonck, R. and J.G. Miller, (1980), "Designing Production Planning and Control System", Journal of Operations Management, Vol: 1, N: 1 .

Veleva, V., Ellenbecker, M., (2000), "A proposal for measuring business sustainability: addressing shortcomings in existing frameworks", GMI, 31(Autumn 2000): 101-119.

Wagner, M., Schaltegger, S., (2004), "The Effect of Corporate Environmental Strategy Choice and Environmental Performance on Competitiveness and Economic Performance: An Empirical Study of EU Manufacturing", European Management Journal, Vol. 22, No. 5, pp. 557-572.

Walsh, B., (2007), "How Business Saw the Light”, Time, New York, Vol. 169, Iss. 3, pg. 56.

Ward, P.T., and R. Duray, (2000), "Manufacturing Strategy in Context: Competitive Strategy and Manufacturing Strategy", Journal of Operations Management, Vol:18.

Wheelwright, S.C., (1984), "Manufacturing Strategy: Defining the Missing Link”, Strategic Management Journal, Vol:5, N:1.

Yontar, İ.G., (2008), "Sürdürülebilir Çevre ve Ekonomi İçin Bir Araç: Türkiye'de ISO 14001 Çevre Yönetim Sistemi Standardı”, Review of Social, Economic \& Business Studies, Vol.9/10, 477-500.

Youndt, M.A., S.A. Snell, J.W. Dean and D.P.Lepak, (1996), "Human Resource Management, Manufacturing Strategy and Firm Performance", Academy of Management Journal, Vol: 36. 